Vol. 6, No. 1, Februari 2018

Efektifitas Media Film dengan Leaflet dalam Peningkatan Pengetahuan Ibu Rumah Tangga tentang DBD di Desa Pekalongan Kabupaten Pati

Dobby Raka Sandi Susetya, Ervi Rachma Dewi

Menggali Kefektifan Peran Ibu dengan Anak Usia Pra Sekolah selama Berada di Rutan Kudus Aliani Nailil Izzah, Sri Hindriyastuti

Perbedaan Kadar BOD Limbah Cair Sebelum dan Setelah melewati Biofilter Tanaman Cattail (Typha angustifolia) Pujo Prasetyo, David Laksamana Caesar

Gambaran Kepatuhan Ibu dalam Pelaksanaan Imunisasi DPT/Hb Lengkap di Puskesmas Punggelan 2 Kabupaten Banjarnegara Lia Aria Ratmawati, Rosiyani Hermawati

Hubungan Riwayat Kontak Penderita dengan Kejadian Tuberkulosis Paru Anak Usia 1-14 Tahun di Balai Kesehatan Masyarakat Pati Risna Endah Budiati, Noor Khoirina

Hubungan Dukungan Keluarga dengan Pemberian ASI Eksklusif pada Bayi di Desa Jambean Kidul Kecamatan Margorejo Nanik Royaningsih, Sri Wahyuningsih

Jumlah Kehamilan dan Kematian Ibu Berdasarkan Letak Wilayah Ketinggian di Kabupaten Pekalongan Rokhani, Indri Astuti Purwanti 


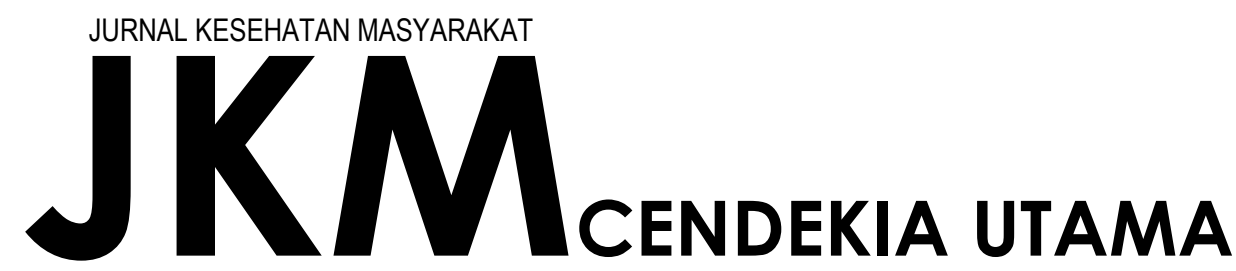


Vol. 6 No. 1

P-ISSN 2338-6347

Februari, 2018

E-ISSN 2580-992X

\section{$\mathbf{J} \mathbf{M}_{\text {cendekia utama }}$}

\section{Editor in Chief}

Eko Prasetyo, S.KM., M.Kes. STIKES Cendekia Utama Kudus, Indonesia

\section{Editorial Board}

Sri Wahyuningsih, S.KM., M.Gizi., STIKES Cendekia Utama Kudus, Indonesia Risna Endah Budiati, S.KM., M.Kes., (Epid), STIKES Cendekia Utama Kudus, Indonesia

Ervi Rachma Dewi, S.KM., M.Kes., STIKES Cendekia Utama Kudus, Indonesia David Laksamana Caesar, S.KM., M.Kes., STIKES Cendekia Utama Kudus, Indonesia

\section{Reviewer}

Sigit Ari Saputro, S.KM., M.Kes., Universitas Airlangga, Surabaya, Indonesia dr. Mahalul Azam, M.Kes., Universitas Negeri Semarang, Indonesia

Eti Rimawati, S.KM., M.Kes., Universitas Dian Nuswantoro, Semarang, Indonesia Didik Sumanto, S.KM., M.Kes. (Epid), Universitas Muhammadiyah Semarang, Indonesia

\section{English Language Editor}

Arina Hafadhotul Husna, M.Pd., STIKES Cendekia Utama Kudus, Indonesia

\section{IT Support}

Susilo Restu Wahyuno, S.Kom, STIKES Cendekia Utama Kudus, Indonesia

JKM (Jurnal Kesehatan Masyarakat) Cendekia Utama merupakan jurnal ilmiah dalam bidang kesehatan masyarakat yang diterbitkan oleh Program

Studi S1 IImu Kesehatan Masyarakat STIKES Cendekia Utama Kudus secara berkala dua kali dalam satu tahun 


\section{KATA PENGANTAR}

Salam MIRACLE,

Puji syukur selalu senantiasa kita panjatkan kehadirat Allah SWT yang telah melimpahkan Rahmah Hidayah dan Ilmu-Nya, sehingga JKM (Jurnal Kesehatan Masyarakat) Cendekia Utama Kudus Vol. 6, No. 1 dapat kembali terbit pada bulan Februari 2018 ini. Pada kesempatan yang baik ini kami menyampaikan ucapan terima kasih dan apresiasi yang setinggi-tingginya kepada bapak ibu mitra bestari, para peneliti, tim redaksi, dan semua pihak yang telah mendukung atas terbitnya JKM Cendekia Utama Vol. 6, No. 1 ini.

JKM Cendekia Utama merupakan jurnal ilmiah di bidang kesehatan masyarakat yang diterbitkan secara berkala 2 (dua) kali dalam setahun oleh Program Studi S1 Ilmu Kesehatan Masyarakat STIKES Cendekia Utama Kudus. JKM Cendekia Utama mempublikasikan informasi ilmiah hasil penelitian dengan kajian: Epidemiologi, Kesehatan Lingkungan, Keselamatan dan Kesehatan Kerja (K3), Promosi Kesehatan, Biostatistik dan Kependudukan, Administrasi Kebijakan Kesehatan (AKK), Manajemen Kesehatan, Gizi Masyarakat, Kesehatan Ibu dan Anak (KIA), Kesehatan Reproduksi, dan kajian-kajian pengembangan ilmu di bidang kesehatan masyarakat.

JKM Cendekia Utama kembali mengundang berbagai ilmuan dari berbagai lembaga pendidikan tinggi maupun peneliti untuk memberikan sumbangan ilmiahnya dalam bentuk artikel ilmiah dari hasil penelitian, laporan/studi kasus, kajian/tinjauan pustaka di bidang kesehatan masyarakat dalam rangka mengatasi permasalahan kesehatan masyarakat yang semakin kompleks.

Redaksi sangat mengharapkan masukan-masukan dari para pembaca dan professional bidang kesehatan masyarakat untuk peningkatan kualitas jurnal dan berharap semoga artikel-artikelyang termuat dalam JKM Cendekia Utama bermanfaat dalam pengembangan ilmu di bidang kesehatan masyarakat.

\section{Pimpinan Redaksi}

Eko Prasetyo, S.KM., M.Kes. 


\section{DAFTAR ISI}

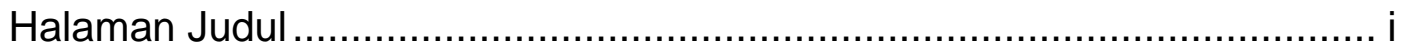

Susunan Dewan Redaksi..................................................................

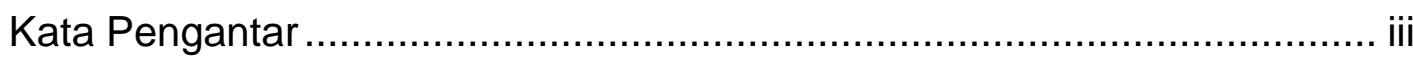

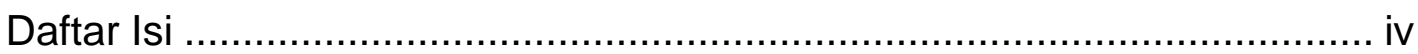

Efektifitas Media Film dengan Leaflet dalam Peningkatan Pengetahuan Ibu Rumah Tangga tentang DBD di Desa Pekalongan Kabupaten Pati Dobby Raka Sandi Susetya, Ervi Rachma Dewi........................................ 1

Menggali Kefektifan Peran Ibu dengan Anak Usia Pra Sekolah selama Berada di Rutan Kudus

Aliani Nailil Izzah, Sri Hindriyastuti........................................................ 16

Perbedaan Kadar BOD Limbah Cair Sebelum dan Setelah melewati Biofilter Tanaman Cattail (Typha angustifolia)

Pujo Prasetyo, David Laksamana Caesar

Gambaran Kepatuhan Ibu dalam Pelaksanaan Imunisasi DPT/Hb Lengkap di Puskesmas Punggelan 2 Kabupaten Banjarnegara

Hubungan Riwayat Kontak Penderita dengan Kejadian Tuberkulosis Paru Anak Usia 1-14 Tahun di Balai Kesehatan Masyarakat Pati Risna Endah Budiati, Noor Khoirina.

Hubungan Dukungan Keluarga dengan Pemberian ASI Eksklusif pada Bayi di Desa Jambean Kidul Kecamatan Margorejo

Jumlah Kehamilan dan Kematian Ibu Berdasarkan Letak Wilayah Ketinggian di Kabupaten Pekalongan

Rokhani, Indri Astuti Purwanti 62

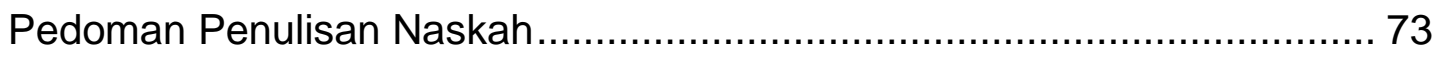

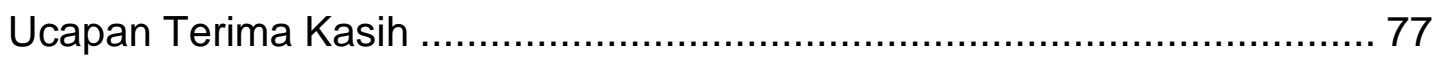




\title{
MENGGALI KEFEKTIFAN PERAN IBU DENGAN ANAK USIA PRA SEKOLAH SELAMA BERADA DI RUTAN KUDUS
}

\author{
Aliani Nailil Izzah ${ }^{1}$, Sri Hindriyastuti ${ }^{2}$ \\ 1,2STIKES Cendekia Utama Kudus \\ srihindriyastuti@gmail.com
}

\begin{abstract}
ABSTRAK
Anak prasekolah merupakan individu yang memiliki potensi luar biasa. Potensi tersebut akan menjadi kompetensi manakala mendapatkan perawatan yang optimal yang mencakup makanan, kesehatan, perhatian, kasih sayang dan pendidikan yang memadai. Maka dari itulah peran ibu disini sangatlah penting bagi anak pada usia pra sekolah. Akan tetapi, peran ibu tersebut mengalami kendala ketika seorang ibu harus berada di dalam lembaga permasyarakatan (rutan). Tujuan dari penelitian ini untuk mengetahui peran narapidana wanita sebagai ibu yang dijalankan ketika berada dalam rutan. Metode penelitian dalam penelitian ini adalah kualitatif dan menggunakan pendekatan fenomenologi. Subjek penelitian ini adalah peran narapidana sebagai ibu. Pengambilan sampel tersebut dilakukan dengan tekhnik purposive sampling, Jumlah informan yang diambil dalam penelitian ini 3 orang narapidana wanita. Dalam pengumpulan data peneliti juga menggunakan alat pengumpul data seperti format pedoman wawancara, buku tulis dan bolpoint dan alat penunjang lainnya seperti alat perekam. Hasil dari penelitian sesuai dengan tema-tema yang telah peneliti bahas yang menurut informan dalam melakukan perannya sebagai ibu sangatlah penting, namun karena keterbatasan yang ada saat dalam rutan membuat para ibu tidak lagi melakukan perannya dalam perawatan fisik, dan mengajarkan anak berbahasa yang baik, dan perannya sebagai pendidik yang lebih ditekankan sebagai pendidik akhlak. Semua peran itu hanya dapat diajalankan para ibu melalui fungsi kontrol saja. Hasil penelitian sesuai dengan tema-tema yang sudah peneliti tentukan untuk lebih mendalami peran narapidana wanita sebagai seorang ibu seperti pada pembahasan yang meliputi : (a)Peran narapidana wanita sebagai seorang ibu dalam perawatan fisik, (b)Peran wanita sebagai seorang ibu dalam mengajarkan anak berbahasa, (c)Peran wanita sebagai seorang ibu sebagai pendidik (Pendidik Akhlak).
\end{abstract}

Kata Kunci: Ibu, peran ibu, anak usia pra sekolah, Rutan

\begin{abstract}
Preschoolers are not just young people who are helpless if they do not obtain assistance from adults around them, but also individuals who basic potential of live. The potential will become a competency when attain adequate care, health, attention, affection and education. In this case, role of mothers here is very important for children at the age of pre-school. The purpose of this research is to find out the role of female prisoners as mothers while in prisons. Qualitative method and using phenomenology approach is used in this study to recover the
\end{abstract}


fenomenon. The subject of this study is the mothers in the prisons. Sampling is done by purposive sampling technique. The number of participants taken in this study were three female prisoners. In the data collection researchers used as interview format, notebook and bolpoint and other supporting tools such as recording equipment. The results of the study in accordance with the themes that researchers have discussed where: performing roles as mothers is very important. However, based on the limitation exists in the prison, causing mothers have no longer perform their role in physical care. Teaching the language in their children becomes another roles mothers cannot perform, and his role as educator who is more emphasized as a moral educator. Otherwise, those roles can only be run by mothers through the control function only. The results of the study are in accordance with the themes that researchers have determined to further explore the role of female prisoners as a mother as in the discussion which includes: (a) The role of female prisoners as a mother in physical care, (b) The role of women as a mother in teaching language to children (c) The role of women as a mother as an educator (Moral educator).

Keywords: mothers, role of women, preschool age children, prisoners. 


\section{PENDAHULUAN}

Perkembangan dan kemajuan dunia saat ini sepertinya semakin kompleks dengan adanya berbagai macam tindakan maupun perilaku manusia. Pola pikir dan tindakan yang di ekspresikan tersebut tidak hanya berupa berpola pikir atau tindakan-tindakan "positif", namun ada juga yang berupa tindakan "negatif" yang merugikan orang lain maupun diri sendiri. Tindakan "negatif" tersebut biasanya disebut dengan kriminalitas. Adapun perilaku negatif tersebut bisa dikaitkan dengan pelanggaran norma-norma sosial, agama, maupun aturan pemerintah. Biasanya pelanggaran aturan pemerintah tersebut akan masuk kedalam kategori kriminalitas[1]. Pertumbuhan yang signifikan pada angka kriminalitas bukan hanya diperoleh tindak kejahatan dari kaum pria, namun semakin banyak pula tindak kriminal yang dilakukan oleh kaum wanita. Selama 3 tahun terakhir di tahun 2013 tindak kriminal yang dilakukan oleh wanita konsisten mengalami peningkatan[2]. Narapidana menghadapi berbagai masalah, tidak hanya dari dalam Lapas, tetapi masalah yang bersumber dari luar Lapas. Terlebih untuk narapidana wanita, dimana menurut Buterfield bahwa narapidana wanita diyakini lebih rentan mengalami mental illness dibandingkan narapidana laki-laki.[3] Narapidana wanita harus menghadapi permasalahan yang bersumber dari luar Lapas misalnya suami yang berniat menceraikan, ayah atau ibu yang sakit dan lebih seringnya mereka mengkhawatirkan siapa yang mengurus anaknya ataupun harus meninggalkan balita yang masih harus di beri Air Susu Ibu (ASI). Sebagaimana diatur dalam Pasal 128 ayat (1) UU kesehatan No. 36 Tahun 2009 mengenai anak balita yang berhak mendapatkan ASI ekslusif dari ibunya. Mereka yang memiliki keluarga tentunya akan mencemaskan keluarga dan anak-anaknya dirumah, terlebih pada anak mereka yang masih menjajaki usia pra sekolah. Seperti pada dasarnya anak pra sekolah adalah mereka yang berusia antara tiga sampai enam tahun[4]. Usia anak sampai 6 tahun disebut juga sebagai golden age (usia emas) dimana perkembangan fisik, motorik, intelektual, emosional, bahasa dan 
sosial berlangsung dengan sangat cepat[5]. Anak prasekolah bukan sekedar manusia muda yang tidak berdaya bila tidak mendapatkan bantuan dari orang dewasa yang berada di sekelilingnya, melainkan individu yang memiliki potensi luar biasa. Potensi tersebut akan menjadi kompetensi manakala mendapatkan perawatan makanan, kesehatan, perhatian, kasih sayang dan pendidikan yang memadai[6]. Maka dari itulah peran ibu disini sangatlah penting bagi anak pada usia pra sekolah.

\section{METODE PENELITIAN}

Metode penelitian yang digunakan peneliti adalah dengan metode kualitatif dan menggunakan pendekatan fenomenologi. Dalam penelitian ini, peneliti berusaha memahami arti dan makna pengalaman partisipan dalam kehidupan, terutama berkaitan dengan peran narapidana wanita sebagai ibu dengan anak pra sekolah di Rutan Kudus. Dalam penelitian ini kreteria partisipan yang bersedia menjadi partisipan adalah: (1) Narapidana wanita II B di Rutan Kudus. (2) Narapidana yang berstatus sebagai ibu dengan anak usia pra sekolah. (3) Narapidana wanita yang bersedia menjadi partisipan. (4) Narapida yang tidak mengalami gangguan jiwa. (5) Tidak bisu dan tidak tuli.

Dalam penelitian ini subjek penelitian ini adalah peran narapidana sebagai ibu, peneliti menggunakan tiga narapidana wanita sebagai informan dalam penelitian ini. Pengambilan sampel dari populasi tersebut dilakukan dengan tekhnik purposive sampling, Penelitian ini dilakukan pada bulan 25 April - 7 Juni 2017 di Rutan Wanita Kelas II B Kudus. Teknik yang digunakan dalam pengumpulan data adalah menggunakan wawancara mendalam (in depth interview). In depth interview menggunakan wawancara yang lebih menggali dan lebih intensif pada topik tertentu. Dalam penelitian ini peneliti menggunakan penelitian kualitatif, dalam penelitian disini yang sebagai instrument adalah peneliti sendiri. Dalam pengumpulan data peneliti juga menggunakan alat pengumpul data seperti format pedoman wawancara, buku tulis dan 
bolpoint dan alat penunjang yang mendukung lainnya seperti alat perekam. Kemudian peneliti melakukan wawancara mendalam (in depth interview) kepada partisipan dalam rentang waktu kurang lebih 15 sampai 30 menit sesuai kesepakatan dengan informan dan dengan karakteristik informan sebagai berikut :

\section{Tabel 1}

Data Informan Penelitian

\begin{tabular}{cccccc}
\hline No & $\begin{array}{c}\text { Inisial } \\
\text { Informan }\end{array}$ & Agama & $\begin{array}{c}\text { Pendidikan } \\
\text { Terahir }\end{array}$ & Pekerjaan & $\begin{array}{c}\text { Alamat } \\
\text { Rumah }\end{array}$ \\
\hline 1 & P1 & Islam & SMA & Sales Perusahaan & Kudus \\
\hline 2 & P2 & Islam & SMK & Buruh Pabrik & Kudus \\
\hline 3 & P3 & Islam & SMA & Pemandu Karaoke & Semarang \\
\hline
\end{tabular}

\section{HASIL DAN PEMBAHASAN}

Penelitian sebelumnya menunjukkan bahwa peran narapidana wanita sebagai ibu terdiri dari penyediaan perawatan fisik, pemberian pendidikan bahasa, membantu anak dalam bersosialisasi, memberikan pendidikan moral, menjadi motivator, pemberian koreksi dan bimbingan kepada anakanak[7]. Adapun tema yang didapat dalam penelitian ini menunjukkan hasil yang berbeda.Dalam penelitian ini, peneliti melakukan penelitian dengan mewawancarai tiga orang narapidana wanita dengan anak usia prasekolah. Partisipan pertama dengan anak usia empat tahun, partisipan kedua dengan anak usia dua tahun dan partisipan ketiga dengan anak usia lima tahun. Dari hasil analisa peran ibu diatas dapat di kategorikan dalam tema-tema sebagai berikut : 


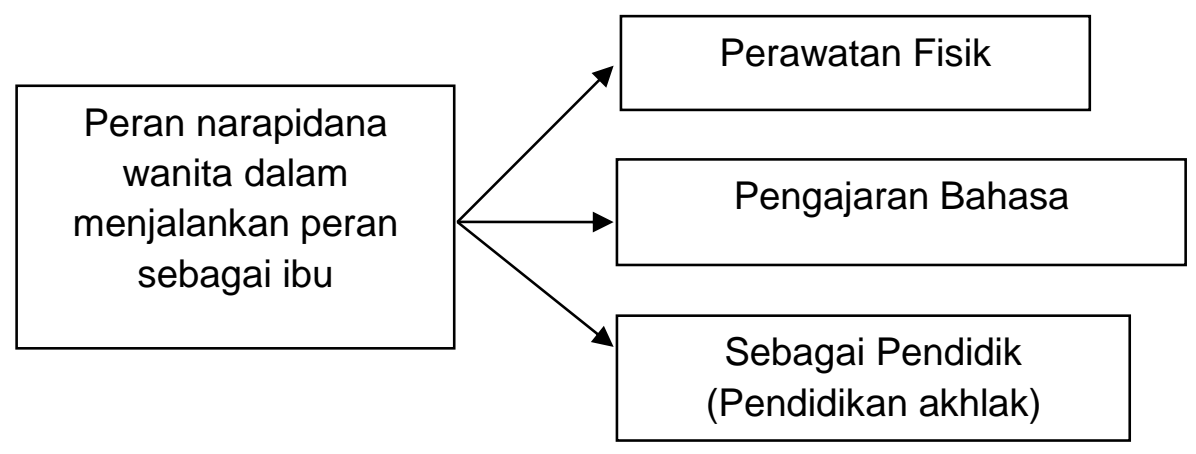

\section{Gambar 1}

a. Perawatan Fisik

Berdasarkan hasil wawancara kepada para partisipan penelitian di Rutan wanita kelas II B Kudus didapatkan hasil bahwa perawatan fisik yang dilakukan oleh para partisipan sebelum menjalani masa tahanan di Rutan wanita kelas II B Kudus hal ini sesuai dengan pernyataan yang telah disampaikan oleh partisipan sebagai berikut :

"... misalnya mengingatkan belajar,potong kuku, gosok gigi, itukan yang sering saya lakukan dirumah..."(P1)

"... Jadi untuk setiap harinya apa.. memandikan atau apa memang saya sendiri..."(P2)

“... Merawat anak itu penting... saya dulu sebelum masuk rutan, selalu rajin memandikan, ..emm.. potong kuku juga..yah .. begitu."(P3)

Dari pernyataan partisipan pertama dan kedua tampak jelas bahwa kedua partisipan sangat memperhatikan kebersihan tubuh anak mereka untuk menunjang tercapainya kesehatan anak yang optimal, dan upaya ibu untuk menjaga kesehatan anak tidak hanya memandikan anak, tetapi menjaga kebersihan dan kesehatan organ tubuh anak yang lainnya. Selain memandikan anak, perawatan fisik lain yang dilakukan oleh ibu sebelum masuk ke rutan adalah mengingatkan anak atau mengajarkan anak untuk gosok gigi, seperti 
pada pernyataan partisipan pertama, tampak bahwa ibu sangat memperhatikan anaknya dengan mengingatkan gosok gigi untuk menghindari karies gigi kepada anak. Karies gigi adalah keadaaan gigi berlubang yang di sebabkan oleh sisa-sisa makanan yang menempel pada permukaan gigi yang akan diubah menjadi asam oleh kumankuman dalam rongga mulut [8]

Orang tua sangat berpengaruh dalam pembentukan perilaku anak[9]. Menurut Persatuan Dokter Gigi Indonesia (PDGI), dalam pemeliharaan gigi anak melibatkan interaksi antar anak, orang tua dan dokter gigi. Sikap dan perilaku orang tua, terutama ibu, memberikan pengaruhyang cukup signifikan terhadap perilaku anak. Berkaitan dengan kesehatan keluarga maka orang tua merupakan sasaran utama dalam promosi kesehatan, karena merupakan peletak dasar perilaku[10]. Sebab secara naluri suka atau tidak mereka harus merawat dan mengasuh anak dari mulai menggendong, memandikan memenuhi kebutuhan anak salah satunya mengembangkan kemampuan anaknya. Sejak masuk rutan, para partisipan menyampaikan bahwa peran ini tidak bisa terlaksana dengan baik. Mereka hanya bisa melaksanakan peran kontrol melalui handphone saat mendapatkan kesempatan untuk menelepon rumah, atau menanyakan kondisi anak saat ada kunjungan keluarga.

b. Pengajaran Bahasa

Bahasa menjadi salah satu fokus peran yang disampaikan oleh semua partisipan, tetapi tidak bisa terlaksana secara langsung karena berada di dalam rutan dan terpisah dengan anak. Berdasarkan hasil wawancara kepada ketiga partisipan didapatkan hasil bahwa sangatlah penting pengajaran bahasa kepada anak. Pengajaran bahasa yang berkaitan dengan perannya sebagai ibu adalah marah kepada anak jika anak menggunakan bahasa yang kurang baik dan mengajarkan anak berbahasa Jawa terlebih menggunakan bahasa krama serta menanamkan kepada anak bahwasannya bahasa adalah 
sebuah indikator terdidik atau tidaknya seorang anak. Peran ibu dalam melibatkan anak dalam les seperti pada pernyataan yang telah dikemukakan oleh para partisipan :

"... saya selalu mengajarkan komunikasi dengan orang lain dengan sebaik mungkin, ya.... Kita mulai dari lingkup rumah dulu lah mbak kaya gitu... kalau kita komunikasi dirumah bagus ya pasti anak dilingkungan juga seperti itu."(P1)

" jadi anak-anak menurut saya itu menurut saya itu masalah bahasa yaa penting banget ,,(P2)

"... untuk bahasanya disamping bahasa jawa itu tiga-tiganya memang saya terapkan bahasa kromo..yaa...penting itu, biar sopan."(P3).

Dari pernyataan dari ketiga partisipan tersebut menjelaskan bahwa peran seorang ibu lebih cenderung untuk membuat pribadi anaknya baik melewati pengajaran bahasa yang di ajarakan oleh ibu untuk membentuk pribadi anak yang baik, yang menurut partisipan pertama memberikan contoh berbahasa yang baik dan benar mulai dari lingkup rumah bisa membuat contoh baik untuk anak, sedangkan menurut partisipan kedua pentingnya pengajaran bahasa adalah untuk membuat anak bertutur kata baik untuk menjadi anak yang baik dan sopan dengan menggunakan bahasa Jawa sebagai bahasa pokok. Hal ini sependapat dengan penelitian yang menyatakan bahwa orang tua (ibu) adalah orang pertama yang mengajak anak untuk berkomunikasi, sehingga anak mengerti bagaimana cara berinteraksi menggunakan bahasa [11].

c. Peran wanita sebagai seorang ibu sebagai pendidik (Pendidik Akhlak)

Orang tua menjadi pendidik adalah bukan karena keputusan kemauan, melainkan karena memenuhi panggilan yang bersifat etis kodrati. Dalam hal ini orang tua khususnya ibu menerapkan pendidikan akhlak kepada anak agar anak tetap menjadi peribadi yang baik. 
"Yah.. akhlak itu penting... saya ajari anak ... yang baik-baik, walaupun saya tidak baik,.. saya ingin anak saya lebih baik.. sesuai panduan agama..." (P1)

"kan ngaji itukan saya mendatangkan kerumah....jadikan yang kecil itu ikut-ikut, ya anak dari stain itu mbak, kan kampong sebelahku ada pondok, mereka pada mondok disitu trus saya mendatangkan kerumah setiap habis maghrib gitu..."(P2)

"Nomer satu,, bagi saya nomer satu, karna saya lebih suka anak saya masuk sekolah cenderung pada Islamic modern..."

"lya saya masukkan TPA kalau sore." (P3)

Pendidikan akhlak yang baik pada anak dalam hal ini mencakup segi spiritual dan emosional anak. Menurut John Gottman dan Joan DeClaire dalam The Heart of Parenting cara pembelajaran pengetahuan emosional adalah dengan menyadari perasaan anak dan mampu berempati, menghibur dan membimbing mereka[12]. Sementara Marsha Sinetar dalam bukunya Spiritual Intelligence mengungkapkan bahwa melalui teladanlah, anak bisa meningkatkan kecerdasan spiritualnya[13]. Ini artinya, upaya untuk meningkatkan kecerdasan emosi, kecerdasan sosial dan kecerdasan spiritual anak tidak bisa seperti halnya upaya meningkatkan kecerdasan intelektual yang bisa dipacu dengan memasukkan ke sekolah-sekolah favorit (yang umumnya adalah sekolah mahal), atau menjejali anak dengan aneka macam les.

\section{SIMPULAN DAN SARAN}

\section{Simpulan}

Hasil dari kesimpulan tersebut menggambarkan tentang tidak efektifnya peran ibu yang bisa dilakukan ketika ibu berada di dalam rutan daripada peran yang dilakukan ibu ketika berada di rumah. Namun hal tersebut tidak menutup kemungkinan narapidana wanita tidak bisa melakukan perannya. Karena naluri seorang ibu tidak dapat lepas dari anak-anaknya. Meskipun terbatas dalam melaksanakan perannya, para 
narapidana wanita masih berusaha semaksimal mungkin untuk tetap menjalankan perannya semaksimal mungkin sebisa mereka melalui media komunikasi jarak jauh maupun kunjungan rumah.

\section{Saran}

Membentuk Self Help Group (SHG) di kalangan para narapidana yang berperan sebagai ibu. Dan sebaiknya pihak Rutan sebaiknya menambah tempat di dalam rutan yang ditujukan bagi anak-anak para narapidana wanita dibawah usia sekolah ataupun anak usia pra sekolah yang masih membutuhkan peranan ibu (narapidana wanita) sebagai ibu. Dan masyarakat lebih bisa memperhatikan anak-anaknya berhubungan dengan pembelajaran secara langsung yang dialami oleh narapidana wanita yang sulit untuk menjalankan perannya di lapas. Pada penelitian ini, peneliti telah mendapatkan macam-macam peran narapidana wanita sebagai ibu dengan anak usia prasekolah. Untuk lebih menggali permasalahan-permasalahan apa saja yang dialami oleh narapidana wanita dalam menjalankan perannya sebagai ibu secara mendalam dan bersifat holistik, maka perlu diadakan penelitian yang tidak hanya berfokus pada narapidana dengan anak usia prasekolah bisa juga dengan anak usia remaja. Dengan demikian berbagai masalah yang terkait dengan pelaksanaan peran narapidana wanita sebagai ibu bisa lebih diminimalkan.

\section{DAFTAR PUSTAKA}

1. Sugono, Dendy, et al., .2008. Kamus Besar Bahasa Indonesia (Jakarta : Pusat Penelitian Bahasa.

2. Kepolisian Negara Republik Indonesia. 2013. Grafik tindak kejahatan berdasarkan golongan. Diakses dari (http://ncic.polri.go.id/pusiknas/indek.php?p=main\&s=sebarankejahat an\&display=none \&displayinfohilang=block).

3. Ardila, F., \& Herdiana. 2013. Penerimaan diri pada narapidana wanita.Jurnal Psikologi Kepribadian dan Sosial. 
4. Patmonodewo S. 2000. Pendidikan anak prasekolah. Rineka Cipta bekerjasama dengan Departemen Pendidikan \& Kebudayaan.

5. Anak AK. 1995. Psikologi Perkembangan. Bandung: Mandar Maju.

6. Rimm SB. 2003. Mendidik dan menerapkan disiplin pada anak prasekolah: pola asuh anak masa kini. Gramedia Pustaka Utama.

7. Hindriyastuti, Sri. 2011. Woman Offenders' Role as a Mother of School Age Children: A Phenomenological Study in the Woman Penitentiary Class II A Semarang. International Journal of Public Health. Malaysia.

8. AR NA. 2015. Psikologi belajar. Al-Fikrah: Jurnal Kependidikan Islam. Aug 2;6.

9. Djamarah SB. 2004. Pola komunikasi orang tua dan anak dalam keluarga (sebuah perspektif pendidikan Islam). Rineka Cipta.

10. Ruscasari, A. M. 2012. Pengaruh Pendampingan Orang Tua Terhadap Kemandirian Belajar Anak di Sekolah pada Siswa Kelas I SD Gugus Mahesa Jenar Kecamatan Ambarawa Kabupaten Semarang Tahun Ajaran 2011/2012 (Doctoral dissertation, Program Studi Pendidikan Guru Sekolah Dasar FKIP-UKSW).

11. Utari, D. I. (2012). 2016. Gambaran Tingkat Kecemasan Pada Warga Binaan Madyawati L, Si M. Strategi Pengembangan Bahasa Pada Anak. Kencana.

12. Werdiningsih, A. T. A., \& Astarani, K. 2012. Peran Ibu dalam pemenuhan kebutuhan dasar anak terhadap perkembangan anak usia prasekolah. Jurnal Stikes. 5(1), 82-98.

13. Rianawati, R. 2014. Peran Ibu dalam Pendidikan Karakter Anak Usia Dini Menurut Pandangan Islam. Raheema. 


\section{PEDOMAN PENULISAN NASKAH JKM}

Jurnal Kesehatan Masyarakat (JKM) STIKES Cendekia Utama Kudus menerima naskah hasil-hasil riset, artikel ilmiah, studi/ analisa kritis, skripsi, tesis, disertasi dan tulisan ilmiah lain di bidang kesehatan masyarakat.

Naskah adalah karya asli penulis/ peneliti, bukan plagiat, saduran atau terjemahan karya penulis/ peneliti lain. Naskah khusus ditujukan kepada Jurnal Kesehatan Masyarakat (JKM) STIKES Cendekia Utama Kudus, belum pernah dipublikasikan di media lain.

Naskah yang dikirim harus disertai surat persetujuan publikasi dan surat pengantar yang ditandatangani peneliti/ penulis.

Komponen naskah:

- Judul, ditulis maksimal 150 karakter, huruf Book Antiqua, ukuran 13, spasi 1

- Identitas penulis, ditulis setelah judul. Terdiri atas nama (tanpa gelar), alamat tempat kerja, nomor telepon/hp dan alamat email.

- Abstrak dalam bahasa Indonesia dan bahasa Inggris, maksimal 200 kata, disusun dalam satu alinea, berisi masalah, tujuan, metode, hasil dan 3-5 kata kunci. Untuk naskah dalam bahasa Inggris, tidak perlu disertai abstrak dalam bahasa Indonesia.

- Pendahuluan, tanpa subjudul, berisi latar belakang, sedikit tinjauan pustaka dan tujuan penelitian.

- Metode penelitian, dijelaskan secara rinci, disain, populasi, sampel, sumber data, teknik/ instrumen pengumpul data, dan prosedur analisis data.

- Hasil dan Pembahasan, mengurai secara tepat dan argumentatif hasil penelitian, kaitan hasil dengan teori yang sesuai dan sistematis.

- Tabel atau gambar. Tabel, diberi nomor sesuai urutan penyebutan dalam teks, ditulis 1 (satu) spasi, ukuran 11. Judul singkat, padat dan jelas, terletak di atas tabel. Gambar, diberi nomor sesuai urutan penyebutan dalam teks. Judul singkat, padat dan jelas, terletak di bawah gambar.

- Simpulan dan Saran. Simpulan menjawab masalah penelitian, pernyataan tegas. Saran logis, tepat guna dan tidak mengada-ada, dan ada keterkaitan dengan keberlanjutan penelitian

- Rujukan/ referensi ditulis sesuai aturan Vancouver, urut sesuai dengan pemunculan dalam keseluruhan teks, maksimal 25 rujukan dan 75 persen merupakan publikasi dalam 10 tahun terakhir. 
Naskah sebanyak 15-25 halaman kuarto, batas atas-bawah-tepi kiri-tepi kanan (cm) : 4-3-4-3, spasi 1,5, jenis huruf: arial, ukuran 12, format Microsoft word, dalam bentuk softfle dan 3 (tiga) eksemplar dalam bentuk print out.

Naskah dikirim ke alamat : Redaksi Jurnal Kesehatan Masyarakat (JKM) STIKES Cendekia Utama Kudus, Jl. Lingkar Raya Km.05 Jepang Mejobo Kudus 59381.

Kontak langsung dapat melalui:

- Eko Prasetyo : 081228475759 / 081575435102

- Sri Wahyuningsih : 085740572288

Naskah juga dapat dikirim melalui email : jkm.cendekiautama@gmail.com

\section{Contoh penulisan daftar pustaka :}

\section{Artikel Jurnal Penulis Individu}

Sloan NL, Winikoff B, Fikree FF. An ecologic analysis of maternal mortality ratios. Stud Fam Plann 2001;32:352-355.

\section{Artikel Jurnal Penulis Organisasi}

Diabetes Prevention Program Research Group. Hypertension, insulin, and proinsulin in participants with impaired glucose tolerance. Hypertension.2002;40(5):679-86

\section{Artikel Jurnal di Internet}

Goodyear-Smith F and Arroll B, Contraception before and after termination of pregnancy: can we do it better? New Zealand Medical Journal, 2003, Vol. 116, No. 1186, <http://www.nzma.org.nz/journal/1161186/683/content. pdf>, accessed Aug. 7, 2007.

\section{Buku Dengan Nama Editor sebagai penulisnya}

Lewis G, ed. Why mothers die 2000-2002: the confdential enquiries into maternal deaths in the United Kingdom. London: RCOG Press; 2004.

\section{Buku yang Ditulis Individu}

Loudon I. Death in childbirth. An international study of maternal care and maternal mortality 1800-1950.London: Oxford University Press, 1992.50

\section{Buku yang Ditulis Organisasi}

Council of Europe, Recent Demographic Developments in Europe 2004,Strasbourg, France: Council of Europe Publishing, 2005. 


\section{Artikel dari Buletin}

Ali MM, Cleland $\mathrm{J}$ and Shah $\mathrm{IH}$, Condom use within marriage: a neglected HIV intervention, Bulletin of the World Health Organization, 2004, 82(3):180-186.

\section{Paper yang Dipresentasikan dalam Pertemuan IImiah/Konferensi}

Kaufman J, Erli Z and Zhenming X, Quality of care in China: from pilot project to national program, paper presented at the IUSSP XXV International Population Conference, Tours, France, July 18-23, 2005.

\section{BAB dalam Buku}

Singh S, Henshaw SK and Berentsen K, Abortion: a worldwide overview, in: Basu AM, ed., The Sociocultural and Political Aspects of Abortion,Westport, CT, USA: Praeger Publishers, 2003, pp. 15-47.

\section{Data dari Internet}

U.S. Bureau of the Census, International Data Base, Country summary: China, 2007, <http://www.census.gov/ipc/www/idb/country/chportal.html>, accessed Aug. 12, 2007.

\section{Disertasi}

Lamsudin R. Algoritma Stroke Gadjah Mada (Disertasi). Yogyakarta: Universitas Gadjah Mada. 1997

\section{Makalah dalam Surat Kabar}

Banzai VK, Beto JA. Treatment of Lupus Nephritis. The Jakarta Post 1989; Dec 8; Sect A.5(col 3)

\section{Kamus}

Ectasia. Dorland's Illustrated Medical Dictionary.27th ed. Philadelphia: Saunders, $1988 ; 527$ 


\title{
UCAPAN TERIMA KASIH DAN PENGHARGAAN
}

\author{
Kepada Yang Terhormat : \\ Sigit Ari Saputro, S.KM., M.Kes. \\ Universitas Airlangga, Surabaya, Indonesia \\ dr. Mahalul Azam, M.Kes. \\ Universitas Negeri Semarang, Indonesia \\ Eti Rimawati, S.KM., M.Kes. \\ Universitas Dian Nuswantoro, Semarang, Indonesia \\ Didik Sumanto, S.KM., M.Kes. (Epid) \\ Universitas Muhammadiyah Semarang, Indonesia \\ Selaku reviewer (Mitra Bestari) dari \\ Jurnal Kesehatan Masyarakat (JKM) Cendekia Utama \\ STIKES Cendekia Utama Kudus
}

